\title{
Primary central nervous system lymphoma presenting as choreoathetosis
}

\author{
Kazuyuki Noda, ${ }^{1}$ Nobutaka Hattori, ${ }^{2}$ Yasuyuki Okuma ${ }^{2}$
}

${ }^{1}$ Department of Neurology, Juntendo University, Shizuoka Hospital, Izunokuni, Shizuoka, Japan

${ }^{2}$ Department of Neurology, Juntendo University, Bunkyo-ku, Japan

\section{Correspondence to} Dr Kazuyuki Noda, k-noda@juntendo.ac.jp

Accepted 19 March 2014
CrossMark

To cite: Noda K, Hattori N, Okuma Y. BMJ Case Rep Published online: [please include Day Month Year] doi:10.1136/bcr-2013203353

\section{DESCRIPTION}

A 49-year-old man developed right hemiparesis and choreoathetosis involving his right upper and lower extremities. His choreoathetosis worsened with attempts at action or posture. Neurological examination showed mild dysarthria, and right upper motor neuron facial palsy. His gait was almost normal. There was no loss of pain sensation or proprioception. Brain MRIs showed high-intensity areas in the left cerebral peduncle, subthalamic nucleus, thalamus and adjacent posterior limb of internal capsule (PLIC) on fluid-attenuated inversion recovery images (figure 1). Coronal T1-weighted images showed contrast-enhancing lesions in PLIC that extended into the cerebral peduncle (figure 2). A brain biopsy revealed a primary central nervous system lymphoma (PCNSL) of the diffuse large B-cell type. The patient was started on three cycles of methotrexate-based chemotherapy followed by whole-brain radiotherapy at a dose of 56 Gy including a boost to the tumour site showing radiological responses. His movement disorders completely resolved following the treatment.

In an MRI study of PCNSL at presentation, $15.7 \%$ of all lesions involved the basal ganglia and thalamus. ${ }^{1}$ Furthermore, choreoathetosis associated with PCNSL are uncommon. Poewe $e t a l^{2}$ reported the case of a patient presenting with arm chorea due to lesions in the contralateral caudate, putamen, a large part of the thalamus and the subthalamic nucleus. Tan $e t a l^{3}$ reported the case of a patient with isolated choreoathetosis due to lesions in the globus pallidus and subthalamic nucleus, extending into the substantia nigra. In this patient, his choreoathetosis may be due to the interruption of the basal ganglia-thalamocortical circuitry.
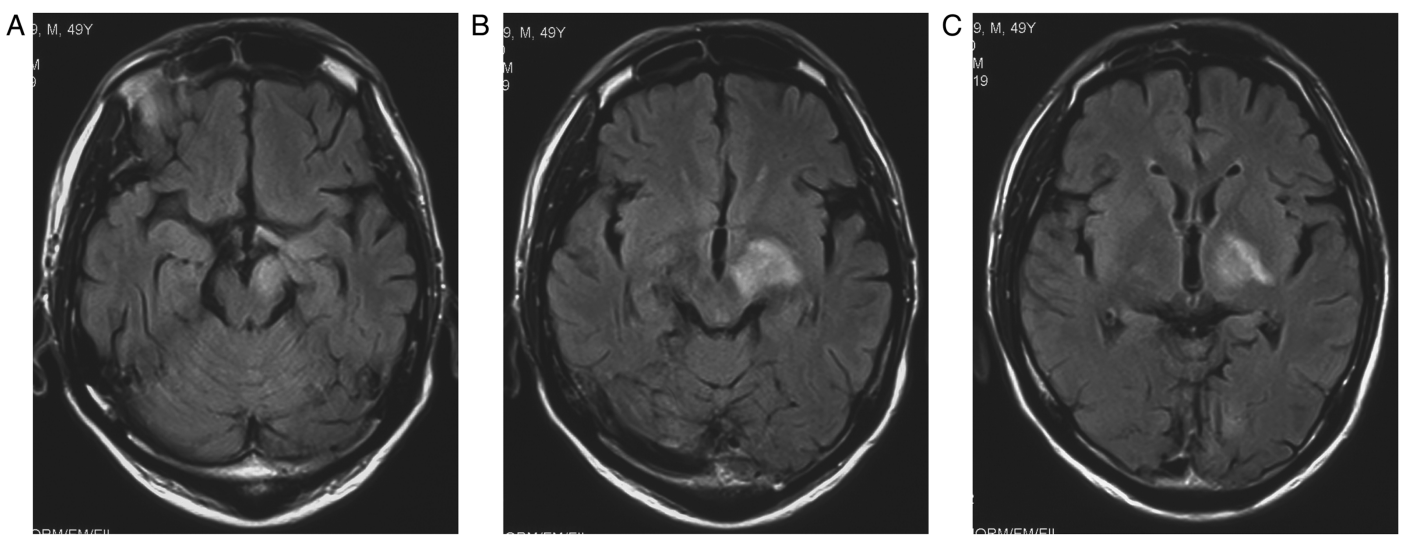

Figure 1 (A-C) Axial fluid-attenuated inversion recovery MRIs showing hyperintense lesions involving the left cerebral peduncle, subthalamic nucleus, thalamus and adjacent posterior limb of internal capsule.
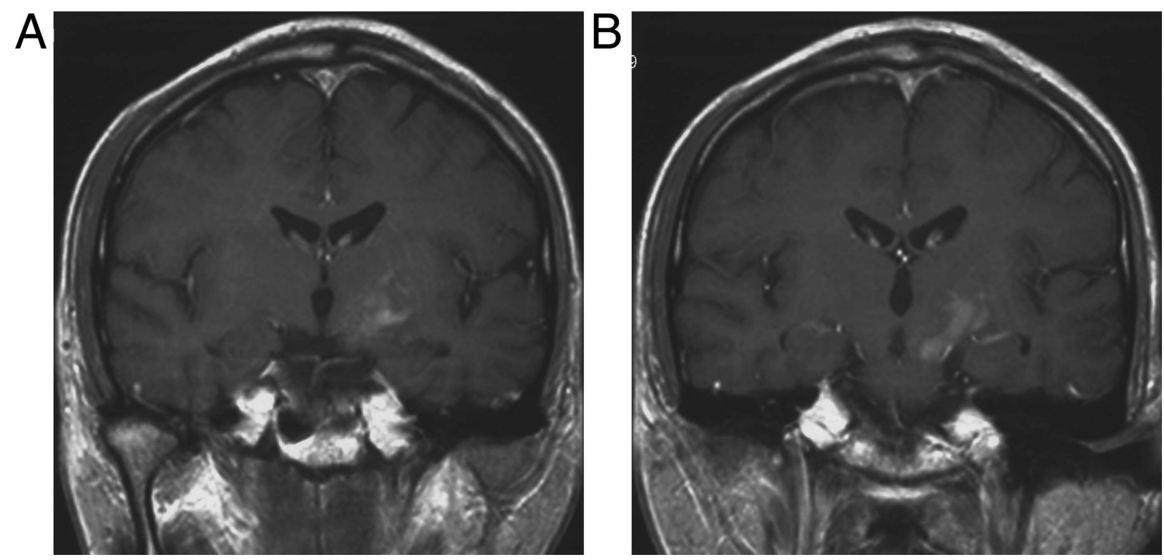

Figure 2 (A and B) Coronal T1-weighted MRIs showing contrast-enhancing lesions of posterior limb of internal capsule that extended into the cerebral peduncle. 


\section{Learning points}

- We report an unusual presentation of primary central nervous system lymphoma (PCNSL) manifesting as choreoathetosis with basal ganglia-thalamocortical circuitry.

- When confronted with a patient with choreoathetosis, PCNSL involving the basal ganglia should be considered in the differential diagnosis.

- PCNSL is commonly found near the subarachnoid space.

\section{REFERENCES}

1 Bühring U, Herrlinger U, Krings T, et al. MRI features of primary central nervous system lymphomas at presentation. Neurology 2001;57:393-6.

2 Poewe WH, Kleedorfer B, Willeit J, et al. Primary CNS lymphoma presenting as a choreic movement disorder followed by segmental dystonia. Mov Disord 1988;3:320-5.

3 Tan EK, Chan LL, Auchus AP, et al. Reversible choreoathetosis in primary cerebral lymphoma: clinicoradiologic correlation. Eur Neurol 2003;50:53-4.

Copyright 2014 BMJ Publishing Group. All rights reserved. For permission to reuse any of this content visit http://group.bmj.com/group/rights-licensing/permissions.

BMJ Case Report Fellows may re-use this article for personal use and teaching without any further permission.

Become a Fellow of BMJ Case Reports today and you can:

- Submit as many cases as you like

- Enjoy fast sympathetic peer review and rapid publication of accepted articles

- Access all the published articles

- Re-use any of the published material for personal use and teaching without further permission

For information on Institutional Fellowships contact consortiasales@bmjgroup.com

Visit casereports.bmj.com for more articles like this and to become a Fellow 